\title{
Induksi Mutasi Kromosom dengan Kolkisin Pada Bawang Putih (Allium sativum L.) Kultivar 'Kesuna Bali' (Induced Chromosome Mutation Using Colchicine in Garlic (Allium sativum Linn.) Cultivar 'Kesuna Bali')
}

\author{
Made Pharmawati ${ }^{1^{*}}$, Ni Luh Ayu Jami Wistiani ${ }^{1)}$ \\ 1) Program Studi Magister Biologi, Program Pascasarjana, Universitas Udayana, Jalan PB \\ Sudirman, Denpasar, Bali. \\ *)Email korespondensi pharmawati@hotmail.com
}

Diterima 12 Januari 2015, diterima untuk dipublikasikan 25 Februari 2015

\begin{abstract}
Abstrak
Tanaman bawang putih (Allium sativum L.) adalah tanaman holtikultura yang memiliki banyak manfaat terutama umbinya yang umumnya digunakan sebgai bumbu dan obat. Salah satu kultivar bawang putih yang ditanam di Bali adalah 'Kesuna Bali' yang hanya memiliki satu siung. Salah satu cara untuk memperbaiki karakter tanaman adalah dengan cara induksi mutasi kromosom dengan kolkisin. Penelitian ini bertujuan menganalisis pengaruh perlakuan kolkisin terhadap indeks stomata dan jumlah kromosom dari tanaman 'Kesuna Bali'. Penelitian menggunakan Rancangan Acak Kelompok dengan enam ulangan. Perlakuan kolkisin yang digunakan adalah 5\%, 10\% dan 20\%. Hasil penelitian menunjukkan bahwa perlakuan kolkisin menurunkan indeks stomata dan meningkatkan jumlah kromosom. Kromosom triploid $(2 n=3 x=24)$ dihasilkan pada perlakuan kolkisin $20 \%$. Kata kunci : Allium sativum L., 'Kesuna Bali', kolkisin, mutasi, sitologi
\end{abstract}

\begin{abstract}
Garlic (Allium sativum L.) is a horticultural crop that has many benefits, especially as spice and traditional medicine. One of garlic cultivars planted in Bali is 'Kesuna Bali' which only has one clove. To improve characters of 'Kesuna Bali', modification of 'Kesuna Bali' properties can be done by means of induced mutation using colchicine. This research aims to analyse the effect of colchicine on stomata index and the number of chromosomes of 'Kesuna Bali'. This research used randomized block design with six replicates. In this experiment the concentration of colchicine used were 5\%, 10\% and 20\%. The results of this study showed that colchicine treatment of $20 \%$ resulted in the lowest stomata index and there was an increase in chromosome number. Colchicine at concentration of $20 \%$ resulted in triploid chromosome set $(2 n=3 x=24)$.

Keywords: Allium sativum L., 'Kesuna Bali', cholchicine, mutation, cytology

PENDAHULUAN

Tanaman bawang putih (Allium

sativum L.) adalah tanaman holtikultura yang memiliki banyak manfaat terutama umbinya yang digunakan sebagai bumbu dan dapat

mengobati beberapa penyakit seperti infeksi pernafasan dan untuk meningkatkan vitalitas tubuh (Pratimi 1995). Wijaya et al. (2014) menyatakan bahwa produksi bawang putih di Indonesia belum mampu
\end{abstract}


memenuhi permintaan kebutuhan pangan masyarakat sehingga menyebabkan selisih dan kekosongan yang cukup besar antara konsumsi dan produksi dalam negeri.

Pada tahun 2012 produksi bawang putih Indonesia adalah 296.500 ton, sementara permintaan bawang putih nasional sebesar 400.000 ton. Untuk memenuhi kebutuhan bawang putih nasional, pemerintah Indonesia melakukan impor bawang putih tahun 2013 sebesar 320 ribu ton terutama impor bawang putih asal Cina. Impor bawang putih ini disebabkan oleh beberapa kendala seperti luas lahan yang sempit, biaya produksi tinggi, kualitas bibit bawang putih yang digunakan rendah serta ketergantungan masyarakat Indonesia terhadap konsumsi bawang putih (BPS 2012).

Salah satu kultivar bawang putih yang ditanam di Bali adalah 'Kesuna Bali' yang hanya memiliki satu siung sedangkan bawang putih biasa memiliki banyak siung. Kualitas bibit 'Kesuna Bali' yang rendah dan mudah terserang penyakit menyebabkan para petani mengganti penanaman'Kesuna Bali' dengan bawang putih biasa. Keunggulan yang dimiliki oleh 'Kesuna Bali' yaitu rasa yang dihasilkan lebih pedas dibandingkan dengan bawang putih biasa. Selain itu kandungan antimikroba pada senyawa kimia 'Kesuna Bali' lebih besar dibandingkan bawang putih biasa sehingga sering digunakan sebagai bahan obat tradisional (Pratimi, 1995). Untuk meningkatkan produksi 'Kesuna Bali' diperlukan perbaikan sifat genetik dan agronomik. Perbaikan sifat genetik 'Kesuna Bali' tidak dapat dilakukan dengan persilangan karena sebagian besar genus Allium tidak memiliki bunga. Perbaikan sifat dapat diupayakan dengan cara lain di antaranya dengan induksi mutasi (Chahal dan Gosal 2002, Soedjono 2003).

Salah satu induksi mutasi yang dikenal adalah induksi polipoid (Suryo 2007). Induksi poliploid dapat dilakukan dengan pemberian mutagen kimia seperti kolkisin pada jaringan meristem tanaman (Sofia 2007). Senyawa ini dapat menghalangi terbentuknya benang-benang spindel pada pembelahan sel sehingga menyebabkan terbentuknya individu poliploid. Penggunaan kolkisin ini dapat meningkatkan jumlah kromosom Penelitian pada bawang merah menunjukkan bahwa terdapat variasi bentuk, ukuran dan jumlah kromosom pada ujung akar bawang merah akibat pemberian kolkisin (Suminah et al. 2002).

Menurut Suminah et al. (2002) perendaman kolkisin konsentrasi $1 \%$ selama 6 jam dapat menambah jumlah kromosom pada bawang merah (Allium ascolinum L.) menjadi tetraploid $(2 \mathrm{n}=4 \mathrm{x}=32)$, pentaploid $(2 n=5 x=40)$, heksaploid $(2 n=6 x=48)$, septaploid $\quad(2 n=7 x=56)$, oktaploid $(2 n=8 x=64) \quad$ dan nonaploid $(2 n=9 x=72)$. Variasi genetik pada tingkat ploidi juga dapat dilihat dari indeks stomata tanaman. Penelitian Lu dan Bridgen (1997) melaporkan bahwa tanaman Alstroemaria $\mathrm{sp}$ diploid mempunyai 39 stomata per $\mathrm{mm}^{2}$ dan yang tetraploid mempunyai kerapatan stomata lebih rendah, yaitu 22 stomata per $\mathrm{mm}^{2}$. Tujuan penelitian ini adalah menganalisis pengaruh perlakuan kolkisin terhadap jumlah kromosom dan indeks stomata dari tanaman kesuna bali (Allium sativum L.). 
METODE

Penelitian ini menggunakan umbi 'Kesuna Bali' yang diambil dari daerah pertanian bawang putih di Desa Pakisan, Kecamatan Sawan, Kabupaten Buleleng, Bali. Perendaman umbi dilakukan dengan kolkisin (non analytical grade dari Biotech Agro) yang pada konsentrasi yang bervariasi yaitu $0 \%$ (kontrol), $5 \%, 10 \%$ dan $20 \%$ selama 12 jam kolkisin, 12 jam air kemudian direndam kembali selama 12 jam pada larutan kolkisin sesuai intruksi perusahaan (Biotech Agro). Selanjutnya umbi ditanam pada polibag dengan diameter $30 \mathrm{~cm}$ dan tinggi $15 \mathrm{~cm}$ lalu dibuat lubang tanam dengan ke dalaman kurang lebih 5-7 $\mathrm{cm}$ menggunakan kayu. Kemudian umbi 'Kesuna Bali' dimasukkan secara tegak ke dalam lubang tanam dan ditutup dengan mulsa jerami setebal $5 \mathrm{~cm}$ pada masing-masing polibag. Pemeliharaan dilakukan dengan menyemprotkan insektisida atau fungisida sebanyak 2 kali dalam satu minggu secara periodik hingga panen. Pemupukan dilakukan pada umur 15 hari setelah masa tanam (MST) dengan pupuk buatan (Hardiyanto et al. 2008).
Daun 'Kesuna Bali' yang berumur \pm 10 MST di potong dan digunakan sebagai bahan untuk perhitungan indeks stomata. Untuk pengamatan kromosom digunakan teknik polibag berlapis dengan tujuan menghindari pencabutan tanaman pada saat pengambilan akar. Rancangan percobaan yang digunakan dalam penelitian ini adalah rancangan acak kelompok (RAK) dengan enam kali ulangan acak digunakan dalam pengamatan.

Indeks stomata diamati dengan memfiksasi daun kesuna bali dalam alkohol $75 \%$, kemudian direndam dalam larutan $\mathrm{HNO}_{3} 25 \%$ selama $15-30$ menit. Selanjutnya daun dicuci dengan aquadest kemudian disayat, sayatan epidermis direndam dalam larutan Bayclin selama 1 - 5 menit lalu diwarnai dengan safranin di atas gelas objek, dicuci aquadest, kemudian ditetesi gliserin $10 \%$ dan ditutup dengan gelas penutup. Selanjutnya diamati dibawah mikroskop dengan perbesaran 400 kali (Palit 2008). Indeks stomata dihitung berdasarkan rumus menurut Lestari (2006) yaitu:

$$
\text { Indeks Stomata (IS) } \underset{\text { (jumlah stomata + jumlah epidermis) }}{=} \frac{\text { jumlah stomata }}{\text {. }}
$$

Pengamatan jumlah kromosom dilakukan dengan metode squash: Ujung akar 'Kesuna Bali' dipotong \pm 2 $\mathrm{mm}$ kemudian difiksasi dengan fiksatif Carnoy (6 etanol : 3 klorofom : 1 Asam Asetat Glasial) selama 12 jam. Setelah fiksasi ujung akar dilunakkan dengan $\mathrm{HCl} 2 \mathrm{~N}$ selama 1-3 menit kemudian diletakkan di atas gelas objek dan ditetesi aceto orcein $2 \%$.
Selanjutnya dilewatkan di atas api bunsen selama 3 menit agar pewarna meresap dengan sempurna kemudian ditutup dengan gelas penutup dan disquash dengan cara diketuk dengan bagian datar pensil lalu diamati di bawah mikroskop dengan perbesaran 400x (Soesanti dan Setyawan 2000).

Data yang ditampilkan dalam bentuk rata-rata persentase indeks 
stomata dan jumlah kromosom. Data dianalisis menggunakan ANOVA (Analisis of Variance). Jika berbeda nyata pada taraf $5 \%$ atau 0.05 diuji dengan uji lanjut Tukey HSD.

\section{HASIL DAN PEMBAHASAN}

Hasil pengamatan menunjukkan rata-rata indeks stomata Hasil uji lanjut Tukey menunjukkan jumlah kromosom tanaman 'Kesuna Bali' pada kontrol berbeda nyata $(\mathrm{P} \leq 0.05)$ terhadap variasi konsentrasi kolkisin yang diberikan (Tabel 2). Pada konsentrasi kolkisin 20\% menghasilkan kromosom triploid $(2 n=3 x=27)$. Gambar 1 menunjukkan gambar kromosom bawang putih pada kontrol dan pada perlakuan kolkisin.

Selain mengakibatkan penambahan jumlah kromsom yang berbeda nyata $(\mathrm{P} \leq 0.05)$ antara kontrol dengan kolkisin $5 \%$ dan $20 \%$ dan tidak berbeda nyata $(P \geq 0.05)$ dengan kolkisin $10 \%$. Rata-rata indeks stomata tanaman kontrol lebih banyak dibandingkan perlakuan kolkisin lainnya. Rata-rata indeks stomata terendah dijumpai pada pemberian konsentrasi kolkisin 20\% (Tabel 1).

senyawa kolkisin juga berdampak terhadap kelainan yang ditimbulkan pada saat pembelahan mitosis yang sering dikenal dengan istilah $\mathrm{C}$-mitosis (Colcichine mitosis) diantaranya terdapat C-profase, C-metafase, Canafase dan C-telofase (Ernawiati 2008). Pada penelitian ini induksi senyawa kolkisin $20 \%$ menyebabkan kesalahan pada proses anafase (Canafase) (Gambar 2).

Tabel 1. Indeks Stomata Kesuna Bali

\begin{tabular}{cc}
\hline \multicolumn{3}{c}{ Indeks Stomata } \\
\hline Kontrol & $0.21 \pm 0.03^{\mathrm{a}}$ \\
Kolkisin 5\% & $0.17 \pm 0.04^{\mathrm{b}}$ \\
Kolkisin 10\% & $0.20 \pm 0.02^{\mathrm{a}}$ \\
Kolkisin 20\% & $0.18 \pm 0.04^{\mathrm{b}}$ \\
\hline
\end{tabular}

Keterangan : Angka adalah rata-rata indeks stomata 'Kesuna Bali' enam ulangan \pm standar error. Angka-angka yang diikuti oleh huruf yang sama pada kolom yang sama berarti tidak berbeda nyata $(P \geq 0.05)$.

Tabel 2. Jumlah Kromosom Kesuna Bali

\begin{tabular}{cc}
\hline \multicolumn{3}{c}{ Jumlah Kromosom } \\
\hline Kontrol & $14.72 \pm 0.47^{\mathrm{a}}$ \\
Kolkisin 5\% & $20.22 \pm 1.55^{\mathrm{b}}$ \\
Kolkisin 10\% & $24.11 \pm 1.14^{\mathrm{bc}}$ \\
Kolkisin 20\% & $27.47 \pm 0.28^{\mathrm{c}}$ \\
\hline
\end{tabular}

Keterangan: Angka adalah rata-rata indeks stomata 'Kesuna Bali' enam ulangan \pm standar error. Angka-angka yang diikuti oleh huruf yang sama pada kolom yang sama berarti tidak berbeda nyata $(P \geq 0.05)$. 
22 JURNAL BIOSLOGOS, FEBRUARI 2015, VOL. 5 NOMOR 1

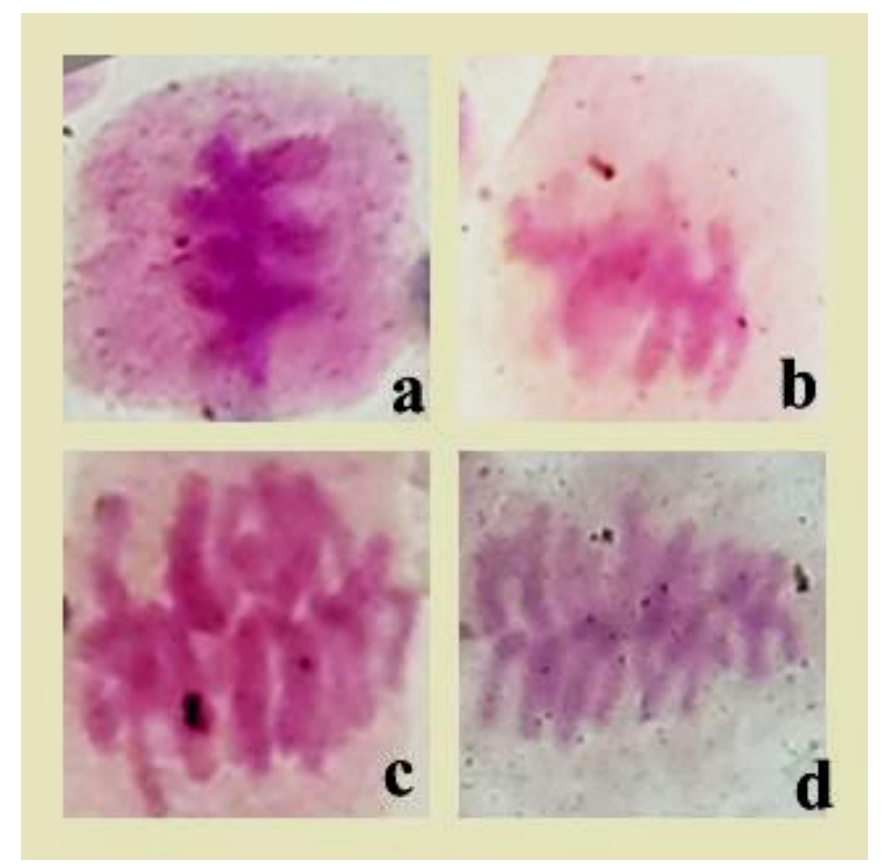

Gambar 1. Foto Kromosom 'Kesuna Bali' (a) Kontrol; (b) Kolkisin 5\% ; (c) Kolkisin 10\%; (d) Kolkisin 20\%.

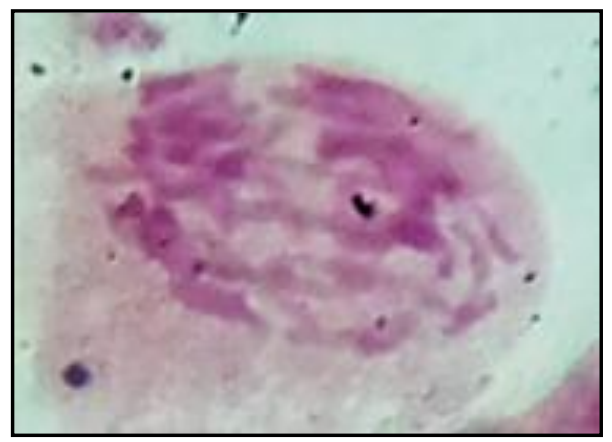

Gambar 2. Foto Kromosom C-anafase Kesuna Bali akibat perlakuan kolkisin.

Berdasarkan pengamatan stomata pada perlakuan konsentrasi kolkisin $10 \%$ didapatkan hasil ratarata indeks stomata yang tidak berbeda nyata dengan kontrol. Sedangkan pada perlakuan kolkisin
$5 \%$ dan $20 \%$ terjadi penurunan indeks stomata (Tabel 1). Tinggi dan rendahnya rata-rata indeks stomata yang didapat berkaitan dengan ukuran stomata. Semakin besar ukuran stomata maka menunjukkan semakin 
rendah indeks stomata yang diperoleh, jika ukuran stomata kecil maka rata-rata indeks stomata yang diperoleh semakin tinggi. Pendapat ini didukung oleh penelitian Setyowati et al. (2013) menyatakan bahwa kolkisin konsentrasi 0.5 g.L-1 dan 1 g.L-1 mampu meningkatkan ukuran diameter stomata pada semua jenis kultivar bawang wakegi (Allium $x$ wakegi Araki). Kolkisin mencegah terbentuknya benang-benang spindel pada kromosom sehingga kromosom tidak tertarik kearah kutub dan terjadi penggandaan. Kromosom yang mengganda ini menyebabkan peningkatan diferensiasi pada proplastid sehingga menghasilkan tanaman dengan kandungan klorofil yang tinggi. Kadar klorofil yang tinggi pada tanaman menyebabkan bertambahnya jumlah kloroplas pada sel penutup stomata sehingga berdampak pada peningkatan ukuran diameter stomata (Loveless 1991).

Perlakuan mutagen kimia kolkisin konsentrasi 20\% menyebabkan peningkatan jumlah kromosom 'Kesuna Bali' menjadi $2 n=3 x=27 \quad$ (Gambar 1, Tabel 2). Senyawa kolkisin dapat menghambat terbentuknya benang spindle pada saat mitosis, sehingga kromosom tetap berserakan didalam sel. Pemberian konsentrasi kolkisin yang tinggi dan peredaman dalam jangka waktu yang lama menyebabkan struktur kromosom dalam sel mengalami penggumpalan dan pengkerutan (Suryo 2007). Secara umum pemberian senyawa kolkisin lebih efektif dibandingkan mutagen kimia lain seperti ekstrak etanolik daun tapak dara dalam membuat tanaman poliploid. Hal tersebut mungkin disebabkan karena kolkisin yang digunakan adalah kolkisin murni (pure analytic) yang sudah di purifikasi. Sedangkan kandungan vinkristin dan vinblastin pada tapak dara masih tercampur dengan senyawa lain dalam ekstrak etanolik tersebut (Indraningsih 2010). Pendapat ini didukung oleh penelitian Indraningsih (2008) melaporkan bahwa ekstrak etanolik daun tapak dara dapat menginduksi poliploidisasi bawang merah diploid $(2 n=16)$ menjadi tetraploid $(2 n=4 x=32)$. Induksi poliploidisasi bawang merah dengan ekstrak etanolik daun tapak dara efektif pada konsentrasi $0,1 \%$ dengan perendaman 6, 12, 18, dan 24 jam.

Pada penelitian ini diperoleh kelainan yang diakibatkan oleh kolkisin pada saat pembelahan mitosis (C-mitosis) yaitu kromosom $\mathrm{C}$ anafase (Gambar 2.). Kelainan mitosis pada saat anafase disebabkan oleh senyawa kolkisin mencegah terbentuknya benang-benang spindel yang menyebabkan kromosom gagal berpisah sehingga terjadi penggandaan jumlah kromosom (Karangiannidou et al., 1995). Penyebab lain yang ditimbulkan pada C-anafase adalah anaphase lag. Anaphase lag merupakan kegagalan kromosom atau kromatid untuk bergabung menjadi satu dalam nukleus sel anakan yang mengikuti pembelahan sel, sebagai hasil dari keterlambatan perpindahan (lagging) selama anafase (Strachan dan Andrew 1999).

Senyawa kolkisin dapat menginduksi mutasi secara acak, sehingga memberikan efek yang tidak seragam pada masing-masing sel ditiap individu (Sofia 2007). Pada beberapa perlakuan kolkisin masih ditemukan individu dengan sel yang tetap diploid (2n). Pada penelitian ini sel-sel yang mengalami penambahan jumlah kromosom atau poliploid hanya ditemukan tipe triploid $(2 n=3 x)$. 
Apabila jumlah kromosom yang dihitung berada diatas atau dibawah kelipatan jumlah kromosom dasar maka dapat diduga telah terjadi delesi atau duplikasi kromosom.

Keanekaragaman genetik yang disebabkan oleh mutasi merupakan sumber plasma nutfah untuk program pemuliaan tanaman. Keanekaragaman ini memungkinkan untuk mengetahui banyak karakter gen, sehingga dapat dijadikan sebagai salah satu penemuan kultivar unggul (Anggarwulan et al. 1999, Suryo 1995).

\section{KESIMPULAN}

Perlakuan konsentrasi kolkisin $20 \%$ menyebabkan penurunan indeks stomata. Penggandaan jumlah kromosom pada 'Kesuna Bali' menghasilkan kromosom triploid $(2 n=3 x)$ pada perlakuan konsentrasi kolkisin $20 \%$ serta terjadi kelainan kromosom anafase (C-anafase).

\section{DAFTAR PUSTAKA}

Anggarwulan E, Etikawati N, Setyawan AD (1999) Karyotipe kromosom pada tanaman bawang budidaya (Genus Allium; Familia

Amaryllidaceae). BioSMART1:13-19

Badan Pusat Statistika (2012) Laporan perekonomian Indonesia, Jakarta

Chahal GS, Gosal SS (2002) Principles and procedures of plant breeding biotechnological and conventional approaches. Alpha Sci Int 413-428

Ernawiati E (2008) Efek mutagenik umbi kembang sungsang (Gloriosa superba Lindl.) terhadap pembelahan sel akar umbi bawang bombay. Jurnal Sains MIPA 14 (2): 129-132
Hardiyanto, Devy NF, Supriyanto A (2007) Eksplorasi, karakterisasi, dan evaluasi beberapa klon bawang putih lokal. J Hortikultura 17(4): 307313

Indraningsih E (2008) Induksi poliploidisasi bawang merah (allium cepa I.) dengan ekstrak etanolik daun tapak dara (Catharanthus roseus [L] G. Don.). [Seminar.]. Fakultas Biologi Universitas Gadjah Mada, Yogyakarta

Indraningsih E (2010) Analisis fenotipe dan ploidi tanaman melon (Cucumis melo L.) hasil perlakuan ekstrak etanolik daun tapak dara (Catharanthus roseus [L] G. Don.). [Skripsi]. Fakultas Biologi Universitas Gadjah Mada, Yogyakarta Karangiannidou TH, Elephteriou EP, Tsekos I, Galatis B, Apostolakos P (1995) Colchichine induced paracrystals in root cells of wheat (Triticum aestivum L.). Ann Bot 76: 23-30

Loveless AR (1991) Prinsip-prinsip biologi tumbuhan untuk daerah tropik. PT Gramedia Pustaka Utama, Jakarta

Lu C, Bridgen MP (1997) Chromosome doubling and fertility study of Alstroemeria aurea $x \quad A$. caryophyllea. Euphytica 94: 75-81

Palit JJ (2008) Teknik perhitungan jumlah stomata beberapa kultivar kelapa. teknik litkayasa pelaksanaan lanjutan pada balai penelitian kelapa dan palma lain. Buletin Teknik Pertanian 13: 9-11

Pratimi A (1995) Perbedaan potensi bakteriostatik antara bawang 
putih umbi tunggal dengan bawang putih umbi banyak terhadap bakteri gram positif dan gram negatif. [Skripsi]. Fakultas MIPA Universitas Diponegoro, Semarang

Setyowati M, Endang S, Aziz P (2013) Induksi Poliploidi dengan Kolkisin pada kultur meristem batang bawang wakegi (Allium $x$ wakegi Araki). Jurnal IImu Pertanian 16: 58-76

Soedjono S (2003) Aplikasi mutasi induksi dan variasi somaklonal dalam pemuliaan tanaman. JI Litbang Pertanian 22: 70-78

Soesanti N, Setyawan AD (2000) Petunjuk praktikum mikroteknik hewan dan tumbuhan. Surakarta: Fakultas MIPA Universitas Negeri Solo

Sofia D (2007) Respon pertumbuhan dan produksi mentimun (Cucumis sativus L) dengan mutagen kolkisin. [Karya
Tulis].Fakultas Pertanian Universitas Sumatera Utara, Medan

Strachan T, Andrew PR (1999) Human molecular genetics. $2^{\text {nd }}$ Edition. BIOS Scientific Publishers Ltd, United Kingdom

Suminah, Sutarno A, Setyawan D (2002) Induksi poliploidi bawang merah (Allium $\begin{array}{ll}\text { ascalonicum L.) dengan } & \end{array}$ pemberian kolkisin. Biodiversitas 3 (1) : $174-180$

Suryo (1995) Sitogenetika. Gadjah Mada University Press, Yogyakarta

Suryo (2007) Sitogenetika. Gadjah Mada University Press, Yogyakarta

Wijaya MA, Anindita R, Setiawan, B (2014) Analisis volatilitas harga volalitilitas spillover dan trend harga pada komoditas bawang putih (Allium sativum L.). AGRISE 14: 128-143 